\title{
ANALISIS STRATEGI MARKETING PUBLIC RELATIONS PIZZA HUT CIMAHI DI TENGAH PANDEMI COVID-19
}

\author{
Iis Heryati ${ }^{1}$, Diny Fitriawati $^{2}$ \\ Universitas Adhirajasa Reswara Sanjaya (ARS University), Bandung \\ iisheryati56@gmail.com, dinyfitriawati@yahoo.co.id
}

\begin{abstract}
ABSTRAK
Kerugian restoran akibat adanya pandemi Covid-19 selama Pembatasan Sosial Berskala Besar (PSBB) dalam dua bulan terakhir nilainya mencapai angka triliunan rupiah. Perusahaan harus menerapkan strategi yang tepat untuk menangani kondisi ini. Strategi Marketing Public Relations dinilai sangat efektif oleh setiap perusahaan agar bisa menarik konsumen dan meningkatkan citra baik bagi perusahaan. Tujuan dari adanya penelitian ini, penulis ingin mengetahui dan memahami bagaimana proses kegiatan yang dilakukan dalam melaksanakan strategi Marketing Public Relations tersebut. Metode yang digunakan yaitu metode deskriptif kualitatif dengan pengumpulan data melalui wawancara semi terstruktur, observasi di lapangan, pengamatan sosial melalui berbagai media. Hasil penelitian menunjukan Marketing Public Relations Pizza Hut Cimahi dalam menangani keadaan yang terjadi menerapkan Three Ways Strategy. Three Ways Strategy meliputi Pull Strategy dengan melakukan promosi menggunakan media, Push Strategy dengan memberikan diskon secara berkala, dan Pass Strategy dengan melakukan branding sebagai restoran yang tanggap situasi. Keberhasilan Pizza Hut Cimahi dalam menjalakankan Strategi Marketing Public Relations tersebut dilihat dari adanya pencapaian target penjualan yang lebih tinggi dibandingkan dengan Pizza Hut di daerah lain yaitu Pizza Hut di Kota Bandung.
\end{abstract}

Kata Kunci: Marketing, Public Relations, Pizza Hut.

\begin{abstract}
The restaurant losses as a result of the Covid-19 pandemic and social restrictions on a large scale (PSBB) the past two months achieve a value of the billions rupiah. The company must implement the right strategy to handle this condition. Marketing Public Relations strategies are effective for companies to pull costumer and improve their brand image company. The purpose of this research, the author wants to know and understand how the process of activities is carried out in implementing the Marketing Strategy Public Relations. The method used is qualitative descriptive methods by data collection via semi structured interviews, field observations, social observations via various media. Research shows Marketing Public Relations of Pizza Hut Cimahi to handle of situation implemented Three Ways Strategy. Three ways strategy encompass a "Pull Strategy" by using media promotions, "Push Strategy" by giving periodic discounts, "Pass Strategy" the restaurant that are aware of the situation. Pizza Hut Cimahi success in carrying out the Marketing Strategy Public Relations is seen form the presentation of sales targets that are higher that the Pizza Hut is other areas namely Pizza Hut in the city of Bandung
\end{abstract}

Keywords: Marketing. Public Relations; Pizza Hut. 


\section{PENDAHULUAN}

Pandemi Covid-19 merupakan krisis kesehatan yang besar dan sangat mengkhawatirkan. Menurut artikel yang ditulis Alodokter, Virus Severe Acute Respiratory Syndrome Coronavirus 2 (SARS-CoV-2) merupakan virus yang menyerang sistem pernafasan. Gangguan penyakit karena infeksi virus ini disebut COVID-19. Virus covid-19 bisa menyebabkan gangguan ringan pada sistem pernafasan, infeksi paru-paru yang berat, hingga kematian ${ }^{1}$. Pandemi Covid-19 berdampak terhadap berbagai sektor, tak terkecuali sektor kuliner. Akibatnya, industri kuliner terkena dampak paling signifikan. Banyaknya pengusaha kuliner dan pemilik restoran terpaksa menutup usahanya untuk sementara waktu, dan tak sedikit yang mengalami keterpurukan. Pada akhirnya, perusahan di bidang kuliner dipaksa untuk lebih kreatif dan memikirkan apa yang dibutuhkan pasar. Apalagi perusahaan dibidang jasa pelayanan makanan franchise harus mempersiapkan strategi khusus agar bisa bertahan.

Penulis mencari perbandingan antara penelitian yang terdahulu dengan penelitian yang dilakukan oleh penulis untuk memosisikan penelitian yang dilakukan. Adapun penelitian yang penulis anggap mempunyai relevansi dengan penelitian yang dilakukan yaitu artikel ilmiah dengan judul "Analisis Marketing Pada Pizza Hut Delivery” oleh Iqbal Arif M, Elly Meida Panjaitan dkk. Dalam penelitian ini berfokus pada analisis dari sisi pemasaran pada PHD dan pada website PHD dengan menggunakan tool Customer Relationship Management ${ }^{2}$. Adapun perbedaan terletak dari keadaan dan situasi yang sedang terjadi yaitu covid-19, dari objek penelitianpun ada perbedaan karena penulis meneliti mengenai Pizza Hut Restoran di tengah pandemi covid-19 yang terjadi, penulis ingin menganalisis bagaimana Pizza Hut melakukan strategi marketingnya, media apa saja yang digunakan agar strategi marketing tersebut berjalan dengan baik. Selain artikel ilmiah di atas, penulis juga mengambil referensi lain yaitu penelitian Skripsi oleh Titie Aprilia Nada Rahayu yang berjudul Strategi Marketing Public Relations Kuliner Serang Oleh Dinas Pemuda Olahraga Dan Pariwisata Kota Serang ${ }^{3}$. Terdapat perbedaan dari hal yang di teliti, baik itu objek ataupun masalah yang terjadi, penelitian yang dilakukan oleh saudara Titie terdapat perbedaan berdasarkan jenis strategi, saudara Titie hanya menganalisis strategi Pull dan Push saja untuk membuktikan benar atau tidaknya Dinas Pemuda Olahraga dan Pariwisata melakukan kegiatan promosi dengan melakukan strategi tersebut.

\footnotetext{
${ }^{1}$ Dame C, M. (2020). Virus Corona. Alodokter. http://www.alodokter.com/virus-corona

2 Iqbal, A. M., Panjaitan, E. M., Siregar, M. P., \& Reghita, S. (2015). Analisis Marketing Pizza Hut Delivery. Marketing, 1. https://journal.maranatha.edu/index.php/jutisi/article/view/570

${ }^{3}$ Rahayu, Titie A, N. (2016). Strategi Marketing Public Relations Kuliner Serang Oleh Dinas Pemuda Olahraga Dan Pariwisata Kota Serang [Universitas Sultan Ageng Tirtayasa]. http://repository.fisip-untirta.ac.id/635/
} 
Strategi marketing dirasa sangat efektif untuk menangani kondisi ini, dengan adanya kondisi krisis yang terjadi seperti sekarang ini menuntut banyak pihak untuk memikirkan cara yang tepat agar usahanya tetap berproduksi dan bertahan. Perlu adanya strategi yang beda yang bisa menarik konsumen dan menambah citra baik bagi perusahaan. Strategi Marketing Public Relation menjadi hal yang umum yang dilakukan oleh sebuah perusahaan untuk memperoleh profit berupa kesan baik ataupun keuntungan dari masyarakat luas ataupun konsumen. Begitu pula dengan restoran sekelas Pizza Hut, Pizza Hut harus memikirkan strategi marketing yang tepat agar bisa bertahan di situasi yang krisis ini. Karena pemberlakuan Pembatasan Sosial Berskala Besar (PSBB) akan berdampak pada penjualan. Menurut laporan berita CNBC Indonesia nilai kerugian restoran selama masa Pembatasan Sosial Berskala Besar (PSBB) dalam dua bulan terakhir sudah mencapai angka triliunan rupiah. Besarnya kerugian akibat restoran tidak bisa beroperasi secara normal, yakni akibat pelarangan kebijakan dine-in atau makan di tempat. Sektor restoran termasuk yang terkena imbas akibat dampak adanya pandemi Covid-19 sehingga harus merumahkan dan mem-PHK pekerja ${ }^{4}$.

Penulis berusaha menganalisis mengenai Strategi Marketing Public Relations yang dipersiapkan oleh Pizza Hut Cimahi dalam menghadapi pandemi Covid-19 yang sedang terjadi. Dari uraian di atas penulis menentukan fokus penelitian dari masalah yang sedang terjadi karena adanya pandemi covid-19, penulis akan melakukan analisis deskriptif kualitatif mengenai strategi marketing yang di terapkan oleh Pizza Hut Cabang Cimahi menggunakan Three Ways Strategy selama pandemi terjadi. Teori yang digunakan penulis dalam menentukan permasalah yang terjadi yaitu teori Difusi Inovasi yang dikemukakan oleh Evertt M. Rogers. Manfaat pembahasan dalam penelitian ini yaitu untuk mengetahui strategi yang tepat yang harus diambil ketika dalam kondisi darurat seperti wabah pandemi yang terjadi saat ini. Strategi tersebut akan sangat bermanfaat bagi sektor kuliner ataupun seorang Praktisi Public Relations dalam menentukan suatu tindakan. Agar bisnis berjalan dengan lancar, harus dibarengi dengan strategi yang efisien dan efektif, strategi yang efektif tersebut yang akan dijadikan acuan bagi bisnis yang serupa agar bisa sama-sama melewati masa sulit untuk bertahan dan berkembang. Strategi yang efektif tersebut bisa dijadikan bahan pertimbangan agar perusahaan lebih waspada dan memikirkan kemungkinan-kemungkinan buruk yang akan terjadi.

\section{KAJIAN TEORI}

\section{Marketing Public Relations(MPR)}

4 Sandi, F. (2020). Rugi Rp 1 T, Bisnis Restoran Hancur-Hancuran. CNBC Indonseia. http://www.cnbcindonesia.com/news/20200605193126-4-163494/rugi-rp-1-t-bisnis-restoran-hancurhancuran 
Di dalam buku dengan judul The Marketer's Guide to Public Relations Thomas L. Harris sebagai penggagas pertama mengenai Marketing Public Relations mengungkapkan "Marketing Public Relations is the process of planning and evaluating programs, that encourage purchase and customer through credible communication of information on impression that identify companies and their products with the needs concerns of customers". Kemudian di kutip oleh Ruslan dan dijelaskan tentang Marketing Public Relations sebagai berikut, "Marketing Public Relations adalah suatu proses perencanaan, pelaksanaan dan pengevaluasian program-program yang dapat merangsang pembelian dan kepuasan konsumen melalui komunikasi mengenai informasi yang dapat dipercaya dan melalui kesan-kesan positif yang ditimbulkan dan berkaitan dengan identifikasi perusahaan atau produknya sesuai dengan kebutuhan, keinginan, dan kepentingan bagi para konsumennya" 5 .

Dari pengertian di atas dapat di tarik kesimpulan bahwa Marketing Public Relations adalah suatu proses kerja marketing untuk menarik konsumen menggunakan program kerja Public Relatios agar terciptanya hubungan yang baik antara konsumen dengan instansi. Melalui keberadaannya Marketing Public Relations di perusahaan dianggap efektif, dikarenakan Marketing Public Relations mampu dalam membangun brand awareness dan brand knowledge. Dengan adanya Marketing Public Relations dalam beberapa hal sangat efektif dan dianggap lebih hemat biaya daripada mempromosikan produk melalui iklan. Perkembangan marketing semakin lama semakin hebat, dengan memanfaatkan media yang ada marketing bertraspormasi secara digital. Memanfaatkan media sosial dan media publikasi yang lain seperti website dan aplikasi.

\section{Strategi Marketing Public Relations}

Bentuk-bentuk Marketing Public Relations menurut Philip Kotler dan Kevin Lane Keller terdiri dari

1. Publikasi (Publications), perusahaan mempercayakan perluasan produk berdasarkan dari publikasi materi untuk memengaruhi dan menarik pembeli yang di tuju. Yang termasuk didalamnya membuat laporan tahunan, brosur, artikel, koran perusahaan, majalah dan materi audiovisual.

2. Media identitas (Identity Media), perusahaan perlu membuat identitas yang bisa dikenal oleh masyarakat dengan mudah. Misalnya: logo perusahaan, alat-alat tulis, brosur, tanda, formulir perusahaan, kartu nama, bangunan, seragam, dan peraturan pakaian.

\footnotetext{
${ }^{5}$ Ruslan, R. (2001). Manajemen Humas \& Manajemen Komunikasi: Konsep Dan Aplikasi. Rajawali Perss.
} 
3. Acara (Events), perusahaan bisa menarik perhatian mengenai produk baru ataupun kegiatan perusahaan dengan cara mengadakan acara khusus seperti wawancara, seminar, pameran, kompetisi, kontes dan ulang tahun supaya dapat menjangkau masyarakat luas.

4. Berita (News), salah satu dari tugas utamanya Public Relations adalah untuk membuat ataupun menemukan acara yang sesuai dengan perusahaan, produknya, orang-orangnya atau pegawainya, dan membuat media tertarik untuk membuat berita press release dan hadir dalam press conferences (konferensi pers).

5. Kegiatan Layanan Publik (Public Service Activities), perusahaan bisa membangun image yang positif dengan cara menyumbang uang atau waktu dalam hal-hal yang positif.

6. Pidato (Speeches), semakin tinggi kebutuhan perusahaan untuk dapat menjawab setiap keperluan masyarakat dengan menjawab pertanyaan dari media atau memberikan pengarahan di asosiasi penjualan dan di meeting yang bertujuan untuk membicarakan soal penjualan dapat membangun citra perusahaan.

7. Pensponsoran (Sponsorship), perusahaan dapat mempromosikan mereknya dengan cara mensponsori sebuah kegiatan contohnya kegiatan sosial dengan tujuan yang sangat dihargai seperti acara olahraga atau upacara kebudayaan yang bermanfaat bagi kelangsungan perusahaannya ${ }^{6}$.

Secara umum Marketing Public Relations mengandung tiga (3) taktik (Three Ways Strategy) untuk melaksanakan program pencapaian tujuan, sesuai dengan pengertian Marketing Public Relations. Public Relations merupakan potensi untuk menyandang suatu taktik pull strategy (menarik), merupakan power (kekuatan) sebagai penyandang push strategy (untuk mendorong) dan juga merupakan pass strategy sebagai upaya untuk memengaruhi atau menciptakan opini publik yang menguntungkan ${ }^{7}$. Strategi Marketing Public Relations erat kaitannya dengan sebuah inovasi, di mana dibutuhkannya sebuah inovasi berupa gagasan ataupun cara penyelesaian yang mampu mengubah ke arah hal yang lebih baik. Berdasarkan buku Ilmu, Teori dan Filsafat Komunikasi yang dikemukakan oleh Onong Uchjana Effendy menurut Everett M. Rogers "Difusi adalah proses di mana suatu inovasi dikomunikasikan melalui saluran tertentu dalam jangka waktu tertentu di antara para anggota sistem sosial ${ }^{8}$.

\footnotetext{
${ }^{6}$ Kotler, P., \& Armstrong, G. (1997). Prinsip-Prinsip Pemasaran. Erlangga.

${ }^{7}$ Ruslan, R. (2002). Manajemen Humas dan Komunikasi : Konsep dan Aplikasi. PT Raja Grafindo Persada.

${ }^{8}$ Effendy, O. U. (2003). Ilmu, Teori dan Filsafat Komunikasi. PT Citra Aditya Bakti.
} 
Melihat kasus yang sedang terjadi yaitu pandemi covid-19 inovasi dirasa sangat dibutuhkan berdasarkan situasi dan kebutuhan. Pemasaran online dan digital branding sebagai sarana komunikasi dengan konsumen sangat berperan penting. Di mana Pizza Hut menerapkan inovasi melalui media marketing untuk tetap bertahan dikala pandemi Covid-19 terjadi.

\section{METODE PENELITIAN.}

Penyusunan penelitian ini menggunakan metode deskriptif kualitatif dengan menguraikan keadaan fenomena yang sudah dan sedang berlangsung melalui kalimat berupa wawancara dan simpulan ataupun display data berupa gambar. Objek dari penelitian ini yaitu Pizza Hut Restoran Cimahi yang terletak di Jalan Raya Cibabat NO 114, Cibabat, Cimahi Utara, Kota Cimahi, Jawa Barat, 40522. Informannya yaitu Bapak Hendra Dwi Putranto sebagai Restoran Manajer yang paham mengenai kondisi dan situasi di lapangan. Pizza Hut Cimahi merupakan salah satu cabang pizza hut di bawah naungan PT Sarimelati Kencana dan merupakan restoran pizza satu-satunya yang ada di kota tersebut. Lokasinya berada di tempat yang strategis dekat dengan perkantoran dan permukiman. Restoran pizza ini termasuk restoran yang ramai dengan penjualan yang tinggi. Selama pemberlakuan Pembatasan Sosial Berskala Besar (PSBB) pada bulan Mei kemarin, restoran ini penjualannya terbesar dibandingkan dengan restoran Pizza Hut di Kota Bandung. Teknik pengumpulan data yaitu observasi langsung ke lapangan, wawancara mendalam semi terstruktur, dan dokumentasi. Dalam kegiatannya wawancara dilakukan lebih bebas mengingat akan adanya pandemi covid-19 yang membatasi akan aktivitas dan jarak sosial (physical distancing). Selain itu penulis melakukan pengamatan, melalui media contohnya media sosial, website resmi official Pizza Hut Indonesia restoran, maupun akun Pizza Hut Cimahi, dan berita yang tepercaya lainnya.

\section{HASIL PENELITIAN DAN PEMBAHASAN}

Dari hasil dari wawancara langsung ke lapangan dengan Restoran Manajer yaitu Bapak Hendra Dwi Putranto menyatakan:

"Selama pandemi Covid-19 Pizza Hut Cimahi mengikuti protokol kesehatan yang berlaku dan imbauan dari pemerintah dengan menerapkan protokol kesehatan yang ketat dan soscial distancing. Karena adanya protokol pemberlakuan PSBB dari pemerintah, Pizza Hut Cimahi juga mengikuti instruksi dari di Dinas terkait dengan menutup layanan makan di tempat sementara". 
Berdasarkan data yang diperoleh dari lapangan yaitu di Pizza Hut Cimahi ditemukan pernyataan tertulis sebagai berikut:

1. Dalam rangka memberikan pelayanan yang terbaik untuk para pelanggan, kami dari Pizza Hut Indonesia selalu mengutamakan kenyamanan dan keamanan bersama dengan melakukan beberapa tindakan yang kami selalu terapkan di seluruh Restoran Pizza Hut.

2. Kami memastikan bahwa seluruh restoran selalu dibersihkan setiap saat sesuai dengan prosedur standar dan rutin. Sistem sanitasi dari hulu ke hilir, mulai dari penyimpanan dan penyiapan bahan makanan, segala permukaan yang ada di restoran, peralatan dapur dan makan, salad bar, pegangan pintu, hingga kamar kecil dilakukan setiap hari tanpa ada yang dikecualikan.

3. Seluruh makanan yang disiapkan telah melalui proses yang higienis untuk memenuhi standar kualitas dan keamanan makanan. Setiap bahan makanan didatangkan dari supplier pilihan berkualitas termasuk sayur dan buah-buahan telah dicuci dan disaitasi seblum diproses dan disajikan. Kami tentunya selalu memastikan seluruh makanan matang saat disajikan kepada pelanggan.

4. Seluruh karyawan kami juga telah dan selalu menjalankan prosedur kebersihan secara perorangan; mencuci tangan dengan hand sanitizer adalah keharusan sebelum dan sesudah menangani bahan makanan. Kami juga mewajibkan pemakaian sarung tangan sekali pakai saat bersentuhan langsung dengan bahan makanan.

5. Mempertimbangkan perkembangan terkini kasus virus Covid-19, kami telah memberlakukan prosedur tambahan sebagai bagian dari upaya pencegahan. Kami melakukan screening kepada seluruh karyawan yang akan mulai bekerja setiap harinya. Apabila ada yang menunjukan gejala sakit seperti demam, batuk, pilek dan sebagainya, akan dicatat dan tidak diizinkan untuk bekerja sampai dinyatakan sehat oleh dokter.

6. Kami juga menerapkan prosedur yang sama, terhadap pihak-pihak terkait, antara lain supplier dan vendor, baik barang maupun jasa, yang berurusan dengan restoran atau akan berada di area Pizza Hut Indonesia.

Selain data di atas didapatkan pula nilai statistik yang diperoleh dari Pizza Hut Cimahi dalam menjalankan kegiatan operasionalnya selama pandemi Covid-19. Nilai tersebut mengacu kepada angka penjualan sebelum dan sesudah adanya PSBB. 


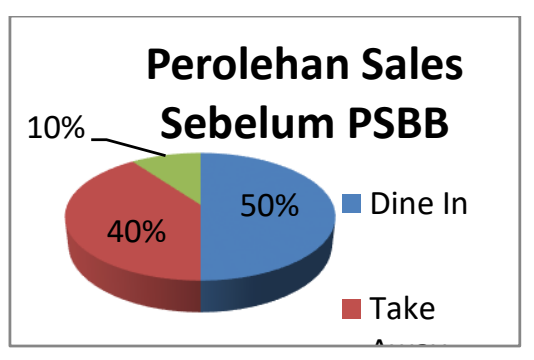

Gambar. 1

Perolehan Sales Sebelum PSBB

Sumber: Temuan Penulis Selama Di lapangan

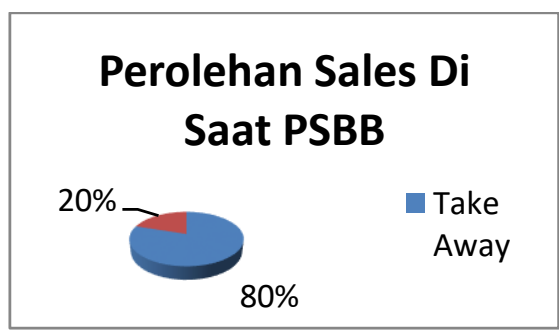

Gambar. 2

Perolehan Sales Di Saat PSBB

Sumber: Temuan Penulis Selama Di lapangan

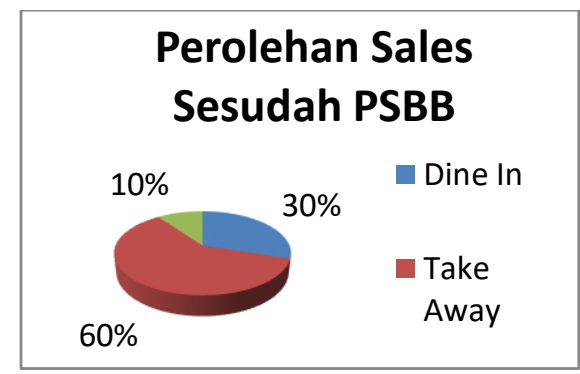

Gambar. 3

Perolehan Sales Sesudah PSBB

Sumber: Temuan Penulis Selama Di lapangan

Dari wawancara dengan Restoran Manajer Pizza Hut Cimahi diperoleh data sebagai berikut.

"Saat ini Pizza Hut Cimahi merupakan restoran pizza yang termasuk ramai dalam penjualannya. Sales yang didapatkan selama PSBB merupakan sales terbesar dibandingkan dengan otlet-otlet Pizza Hut restoran di Bandung meskipun ada penurunan sales dibandingkan sebelumnya".

Bapak Hendra Dwi Putranto juga memberikan informasi mengenai perolehan sales secara keseluruhan baik itu sebelum PSBB, disaat PSBB, dan sesudah PSBB. Sales yang didapatkan sebelum adanya PSBB yaitu 1,3 Miliar, sementara seles yang didapatkan disaat diberlakukannya PSBB yaitu 1,1 Miliar, dan seles sesudah PSBB yaitu 1 Miliar. Restoran 
Manajer Pizza Hut Cimahi juga mengungkapkan bahwa salah satu faktor yang mendukung Pizza Hut Cimahi dalam penjualannya karena Pizza Hut Cimahi merupakan restoran Pizza Hut satu-satunya yang ada di kota tersebut, sehingga tidak adanya persaingan sesama restoran Pizza Hut yang lain. Dari ke-14 outlet restoran Pizza Hut yaitu Pizza Hut Cimahi, Pizza Hut Buah Batu, Pizza Hut Kopo, Pizza Hut Antapani, Pizza Hut Dago, Pizza Hut Riau, Pizza Hut SHB, Pizza Hut Setiabudhi, Pizza Hut City Link, Pizza Hut IP, Pizza Hut BIP, Pizza Hut JATOS, Pizza Hut Paskal, dan Pizza Hut Ciwalk, Pizza Hut Cimahi memperoleh pendapatan sales yang paling tinggi.

\section{Pull Strategy (Menarik)}

Pull Strategy adalah strategi yang digunakan untuk mengarahkan aktivitas pemasaran terutama periklanan dan promosi terhadap konsumen, tujuannya untuk menarik minat konsumen dan akan berdampak pada meningkatnya hasil penjualan. Ketika mempromosikan sebuah produk/ brand butuh adanya media yang bisa mendistribusikan pesan. Media yang digunakan dalam promosi tersebut sangat beragam, diantaranya menggunakan media digital. Pizza Hut memanfaatkan media digital (Digtal Marketing) untuk tetap terhubung dengan konsumen dan khalayak luas. Mengingat jumlah pengguna internet di indonesia sangat banyak, dan Indonesia merupakan salah satu pengakses internet tertinggi di dunia berdasarkan data yang diperoleh dari hasil riset We Are Sosial dan Hootsuite dari total 4,3 miliar penduduk indonesia, separuh lebih dari populasi tersebut, sekitar 56\% atau 2,42 miliar diantaranya sudah mendapatkan akses internet. Dan separuhnya sekitar 2,14 miilar penduduk telah menggunakan sosial media. Indonesia merupakan negara dengan pertumbuhan internet tertinggi ke tiga di dunia, dan banyak lagi kelebihannya 9 .

9 Ramadhan, B. (2020). Data Internet Di Indonesia Dan Prilakunya Tahun 2020. 16 Februari. https://teknoia.com/data-internet-di-indonesia-dan-perilakunya-880c7bc7cd19 


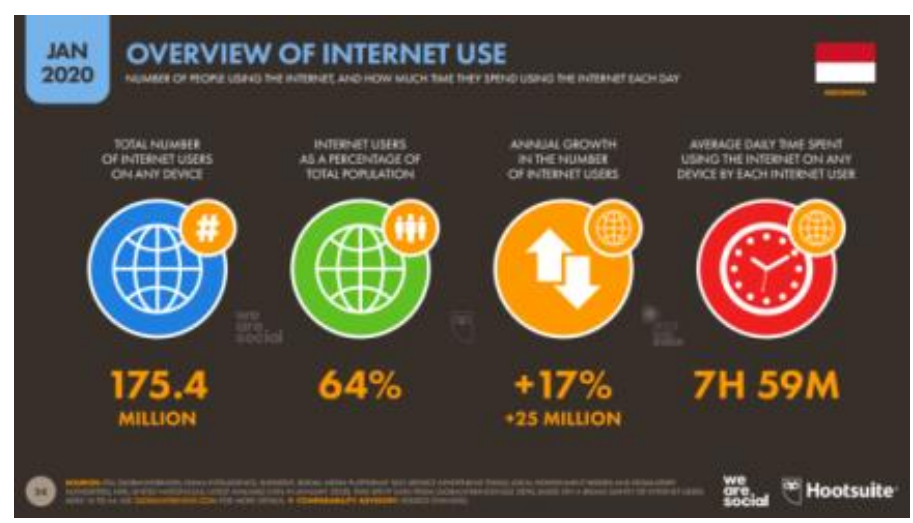

Gambar. 4

Tinjauan Pengguna Internet

Sumber: https://teknoia.com

Tetap terhubung dengan pelanggan di media sosial dan memperkuat digital branding melalui media, termasuk salah satu strategi yang harus diterapkan. Dari kegiatan tersebut penulis melihat bahwa Pizza Hut berusaha menerapkan inovasi dalam bidang penjualannya menggunakan media digital. Media diantaranya ada media sosial (Facebook, Instagram, twitter, Tik-Tok), youtube, media website official resmi Pizza Hut, Iklan di media massa dan media digital seperti televisi dan radio. Melalui media instagram, facebook dan twiter Pizza Hut berupaya untuk terus menjalin hubungan yang baik dengan pelanggan caranya dengan memberikan dukungan dan menkampanyekan tagar \#dirumahaja, selain ikut mendukung pemerintah dalam kampanye tersebut Pizza Hut juga berupaya untuk memperbaiki strategi penjualan dan menyesuaikan dengan keadaan. Contoh strategi yang digunakan yaitu memanfaatkan media sosial tik-tok yang sedang terkenal dikalangan masyarakat dengan \#BerbukaBersamadenganPizzaHut, Pizza Hut mengajak konsumen untuk ikut serta dalam pembuata video Tik-Tok tersebut. Dan untuk pemenang akan mendapatkan paket Triple Box dan e-voucer pizza spesial dari Pizza Hut, dengan menkampanyekan \#pizzahutchallange bertujuan untuk menarik minat konsumen.

\section{Push Strategy (Mendorong)}

Push Strategy adalah strategi yang mendorong konsumen agar konsumen membeli produk dengan memberikan informasi dan pelayanan yang menarik dan menguntungkan. Berdasarkan apa yang ditemukan di lapangan penulis meyakini, bahwa Pizza Hut Cimahi menerapkan Push Strategy di tengah pandemi covid-19 ini yaitu dengan mendorong pelanggan untuk membeli produk dengan adanya diskon melalui promosi-promosi marketing yang berjalan. Promosi secara berkala yang ditawarkan di lapangan yaitu berupa; Promo beli satu gratis satu minuman juice untuk take away berlaku sepanjang hari. Pemberian voucher diskon 50\% Pan Regular 
Meat Lover untuk costumer yang membeli pizza apa saja dan voucher tersebut dapat ditukarkan untuk pembelian pizza berikutnya, untuk makan di tempat atau take away berlaku sampai 31 Maret 2020. Gratis satu pasta (beef spaghetti atau oriental chicken spaghetti) dengan pembelian paket double box.(13-23 April 2020). Promo buy 1 get 1 pizza ( beli pizza ukuran large apa saja gratis 1 pizza pan regular deluxe cheesel tuna melt) (24-30 april 2020) berlaku untuk take away, aplikasi, gofood, dan grabfood. Gratis biaya antar untuk delivery (01- 23 mei 2020). Beli pizza ukuran sedang atau besar gratis garlic bread (01-15 mei 2020), berlaku untuk makan di tempat, take away, delivery, gofood dan grab food. Promo beli 1 gratis 1 pizza ( beli pizza ukuran sedang atau besar gratis pizza ukuran sedang pan pizza dengan topping Cheesy Frank) 15-23 Mei 2020. Beli Triple Box gratis 2 freshtea lychee $350 \mathrm{ml}$ (04-31 mei 2020) untuk take away dan delivery selama persediaan masih ada. Pembelian promo paket yaitu Double Box, Big Box, Triple Box dengan menambah Rp. 50.000 bisa mendapatkan 1 pizza sedang tanpa pinggiran dengan topping apa saja. Paket Fantastic Box (4 pizza personal pan dengan pilihan topping, Tasty Tuna, Chesee Frank, Bbq Beef, Creamy Tomato Chicken, Honey Mustard Chicken)

Berdasarkan data yang diperoleh dari lapangan maupun pengamatan melalui berbagai media, ditemukan bahwa. Pizza Hut cimahi berusaha memaksimalkan penjualan melalui layanan take away dan delivery selama diberlakukannya instruksi dari pemerintah yaitu PSBB. Kegiatan penjualan yang dioptimalkan yaitu berupa jualan pizza express/On The Spot (OTS) yang termasuk kedalam bagian Take Away yaitu berupa kegiatan menjual pizza yang sudah jadi tanpa konsumen menunggu lama. Pizza express di sini dilakukan di suatu tempat khusus yang sudah di pilih, contohnya di pinggir jalan. Pizza Hut Cimahi memilih lima titik penjualan dalam kegiatan OTS, titik-titik tersebut yaitu: Jl. Ciuyah, Jl. Contong, Jl. Kolonel Masturi, dibelakang UNJANI, dan terakhir yaitu Perumahan Permata Cimahi. Selain kegiatan Pizza Express (OTS) Pizza Hut Cimahi juga memberikan layanan Drive True untuk konsumen yang membeli pizza dengan cara take away tanpa keluar dari kendaraan yang digunakannya, konsumen bisa melakukan kegiatan taking order di dalam kendaraanya.

\section{Pass Strategy (Memengaruhi)}

Tujuan dari adanya strategi ini yaitu untuk memengaruhi khalayak luas khususnya konsumen dengan menciptakan image yang baik untuk perusahaan. Berikut adalah kegiatan yang dilakukan oleh Pizza Hut Cimahi untuk memengaruhi khalayak :

1. Melakukan kegiatan branding dan menjadi brand yang tanggap akan situasi 
Di tengah kondisi pandemi yang sedang terjadi, berdasarkan survei di lapangan, penulis menemukan dan menganalisis fakta-fakta yang terjadi di lapangan. Pizza Hut Cimahi berusaha tanggap dengan keadaan yang ada dan memastikan semua berjalan sesuai dengan instruksi yang berlaku di lapangan. Banyaknya hal yang harus diperhatikan dan dipersiapkan untuk menangani kondisi pandemi yang sedang terjadi ini. Pizza Hut memastikan kondisi di lapangan berjalan dengan sebagaimana mestinya tanpa adanya hambatan dan kesalahan misalnya dalam memerhatikan kesehatan dan kebersihan, kesehatan karyawan diperhatikan dengan adanya pemeriksaan suhu tubuh secara rutin dan pemberian vitamin untuk mendukung kesehatan para karyawan, menerapkan kebiasaan wajib yaitu prosedur mencuci tangan sebelum dan sesudah menangani bahan makanan dan menggunakan hand sanitizer secara berkala. Kedisiplinan juga diterapkan dalam menjalankan prosedur kebersihan secara detile dari dapur sampai ke meja pelanggan, membersihkan meja pelanggan secara rutin menggunakan chemical khusus dan membersihkan tempat-tempat atau alat yang biasa di pegang oleh pelanggan atau karyawan sendiri. Mengingatkan kepada pelanggan termasuk driver online (grabfood dan gofood) untuk menjaga kebersihan dengan menyediakan tempat sampah dan tempat mencuci tangan beserta handsoap dan hand sanitizer. Serta pemeriksaan suhu secara rutin untuk pelanggan yang datang.

\section{Memberlakukan Physical Distancing}

Untuk menjadi brand yang tanggap situasi, Pizza Hut ikut menkampanyekan physical distancing melalui media sosial dan melalui konten-konten vidieo yang menkampanyekan untuk tetap berada di rumah. Physical distancing tidak hanya di informasikan melalui media saja, tetapi di lapangan juga melakukan protokol yang sama Pizza Hut Cimahi membatasi jarak antre di area meja kasir, jarak antara meja pelanggan, jaga jarak di area tunggu, jarak antar kursi tunggu, delivery service mengantar makanan tanpa kontak langsung dengan meletakan pesanan di tempat yang sudah di setujui, menyediakan hand sanitizer dan westafel khusus di luar ruangan untuk konsumen yang ingin masuk ke pizza hut cimahi dan pemeriksaan suhu tubuh untuk konsumen yang datang.

Dengan adanya protokol pemberlakuan Pembatasan Sosial Berskala Besar (PSBB), Pizza Hut membuat keputusan untuk menutup sebagian restoran yang beroprasi di Mall yang mengalami penutupan, dan menutup sementara layanan makan di tempat tujuannya untuk menghindari dan mengurangi penyebaran virus covid-19 secara meluas. Selama pandemi Pizza Hut Cimahi menyiapkan solusi untuk konsumen yang tidak mau menunggu pizza lama yaitu dengan menyiapkan pizza express (pizza yang sudah jadi), menyiapkan 
layanan Drive Thru untuk memudahkan para konsumen yang membeli pizza. Dengan pengambilan pesanan dilakukan di dalam mobil, sehingga konsumen tidak turun dari mobil untuk melakukan pemesanan. Hal tersebut dilakukan dengan menerapkan protokol keamaan untuk meningkatkan kepercayaan pelanggan.

3. Melakukan Kegiatan Layanan Publik

Untuk ikut mendukung dan memberikan suport kepada pemerintah baik itu tenaga medis, Pizza Hut juga ikut berpartisipasi dalam kegiatan Berbagi Bersama Pizza Hut, kegiatan tersebut berupa donasi pizza, pemberian masker gratis, dan pemberian disinfektan gratis untuk para pejuang kemanusiaan garda penanganan terdepan Covid-19 di rumah sakit dan puskesmas. Donasi pizza yang diberikan yaitu berjumlah 10 Pan Large Pizza, untuk tempat yang dipilih dalam kegiatan donasi ini di kota Bandung ataupun Cimahi yaitu: RS Hasan Sadikin Bandung, RS Dustira Cimahi dan RS Rotinsulu. Kegiatan ini bertujuan untuk membantu dan saling mensuport agar beban pemerintah atau tenaga medis menjadi berkurang dan keadaan bisa secepatnya pulih seperti sediakala.

\section{KESIMPULAN}

Berdasarkan gambaran hasil penelitian, kesimpulan yang dapat diambil dalam penelitian ini adalah sebagai berikut: strategi yang digunakan Marketing Public Relations Pizza Hut Cimahi yaitu Three Ways Strategy dengan poin-poin diantaranya: Pull Strategy, yaitu dengan menarik konsumen menggunakan media digital diantaranya media sosial, media massa, yang berisi akan informasi mengenai Pizza Hut, salah satu contohnya dengan membuat sebuah event special yaitu challenge menggunakan media sosial Tik-Tok berupa video tujuannya untuk menarik khalayak luas.

Push Strtegy, yaitu dengan memberikan promo-promo secara berkala dan kemudahan dalam pemesanan agar konsumen menjadi semakin tertarik dan ingin membeli dengan adanya dorongan keinginan dalam pembelian produk tersebut maka akan menjadi keuntungan untuk perusahaan. Pass Strategy, dalam strategi ini perusahaan berusaha menunjukan kepada khalayak luas khususnya konsumen bahwa perusahaan Pizza Hut merupakan brand yang tanggap akan situasi, dengan memberlakukan Physical Distancing beserta protokol-protokol kesehatan yang berlaku, dan melakukan Kegiatan Layanan Publik. Semua kegiatan di atas dilakukan untuk memperoleh good will, baik itu keuntungan berupa kenaikan sales ataupun kepercayaan dan citra yang baik untuk perusahaan. Pizza Hut Cimahi sudah berhasil dalam menjalakankan strategi tersebut dengan adanya pencapaian target penjualan yang lebih tinggi dibandingkan dengan Pizza Hut di daerah lain yaitu Pizza Hut di Kota Bandung. 


\section{DAFTAR PUSTAKA}

Annisya, V. (2019). Strategi Marketing Public Relations d'BestO Dalam Membangun Brand Awareness melalui Instagram. Proceeding Humanis Universitas Pamulang. http://www.openjournal.unpam.ac.id/index.php/Proceedings/article/view/5566

Dame C, M. (2020). Virus Corona. Alodokter. http://www.alodokter.com/virus-corona Effendy, O. U. (2003). Ilmu, Teori dan Filsafat Komunikasi. PT Citra Aditya Bakti.

Iqbal, A. M., Panjaitan, E. M., Siregar, M. P., \& Reghita, S. (2015). Analisis Marketing Pizza Hut Delivery. Marketing, https://journal.maranatha.edu/index.php/jutisi/article/view/570 Kotler, P., \& Armstrong, G. (1997). Prinsip-Prinsip Pemasaran. Erlangga.

Maryam, \& Wirman, W. (2017). Strategi Marketing Public Relations Dalam Meningkatkan Jumlah Tamu Hotel Pantai Marina Bengkalis. Jurnal Online Mahasiswa UNRI, https://jom.unri.ac.id/index.php/JOMFSIP/article/view/14812

Rahayu, Titie A, N. (2016). Strategi Marketing Public Relations Kuliner Serang Oleh Dinas Pemuda Olahraga Dan Pariwisata Kota Serang [Universitas Sultan Ageng Tirtayasa]. http://repository.fisip-untirta.ac.id/635/

Ramadhan, B. (2020). Data Internet Di Indonesia Dan Prilakunya Tahun 2020. 16 Februari. https://teknoia.com/data-internet-di-indonesia-dan-perilakunya-880c7bc7cd19

Rogers, E. M. (2004). Diffusion Of Innovations. Third Edition. The Free Perss.

Ruslan, R. (2002). Manajemen Humas dan Komunikasi: Konsep dan Aplikasi. PT Raja Grafindo Persada.

Sandi, F. (2020). Rugi Rp 1 T, Bisnis Restoran Hancur-Hancuran. CNBC Indonseia. http://www.cnbcindonesia.com/news/20200605193126-4-163494/rugi-rp-1-t-bisnisrestoran-hancur-hancuran

Tulis, C., \& Wijaya, L. S. (2019). Strategi Marketing Public Relations Dalam Meningkatkan Jumlah Kunjungan Wisatawan Kepulauan Talaud-Sulawesi Utara. Jurnal Komunikasi Universitas Garut, 05. https://journal.uniga.ac.id/index.php/JK/article/view/586 